ИЗВЕСТИЯ АКАДЕМИИ НАУК ЭСТОНСКОН ССР. ТОМ 22 ХИМИЯ * ГЕОЛОГИЯ. 1973, № 4

\title{
KIMASPIS, A NEW PALAEACANTHASPID FROM THE EARLY DEVONIAN OF CENTRAL ASIA
}

In 1967, on the southern slope of Merishkor mountain, the North Nuratau ridge, South Tien Shan, two arthrodira remains were discovered by A. Kim and N. Larin (the Trust "Tashkentgeology", Uzbek SSR). They come from the Dzhalpak Formation, i. e. from an equivalent of the Kunzhak Stage of the Turkestan ridge and the Lochkovian of Barrandian (Kim, Larin, Lesovaya, 1971). The lower part of the Dzhalpak Formation is correlated with the lowermost part of the Lower Devonian, the Borshchov Stage (zone of Monograptus uniformis) of Podolia. And thus the finds are of great interest as they belong to one of the oldest arthrodires.

The palaeacanthaspids and related forms are distributed in the Gedinnian and Siegenian. T. S. Westoll (1967, Text-fig. 1) gave a review of the occurrences of palaeacanthaspids, radotinids and other early arthrodires in Europe. In addition to them and to Kimaspis n. gen. from Central Asia, some other occurrences can be indicated. These are the palaeacanthaspids in Pechora Region, to the north-west from the Urals (Gedinnian), in the north-west of the Siberian platform (Siegenian, Kureika formation) and on Kotelny Island, Soviet Arctic (Siegenian?).

According to the classification given by D. Obruchev (1964), the order Palaeacanthaspidida (Acanthothoraci) contains three genera: Kosoraspis, Palaeacanthaspis and Dobrowlania. The first one occurs in the Upper Lochkovian of the Barrandian (zone of Monograptus hercynicus), and the other genera in the Chortkov Stage of Podolia. The order Radotinida is represented by two genera: Radotina and Holopetalichthys. The first genus comes from the Upper Lochkovian and Pragian of Barrandian and from the Siegenian (Taunus Quartzite) of Rhineland. Holopetalichthys novaki, as far as the "Steinkern" of the skull-roof, the holotype, the only specimen figured by A. Koenen (1895, Pl. 4 fig. 2) is considered, does not markedly differ from the Pragian Radotina species, $R$. tesselata Gross and $R$. prima (Barrande) $=R$. tuberculata Gross. Both these forms and Holopetalichthys are found in the Upper Konieprus Limestone, and so a revision is necessary. There exists, moreover, a third order, Kolymaspidida, represented only by one genus (and species), Kolymaspis. The latter is of the Early Devonian age and is found in north-east Siberia (Kolyma Basin).

It has been pointed out several times that the radotinids are closely related to palaeacanthaspids (Gross, 1959; Westoll, 1967; Miles, 1967, etc.). Here these arthrodires will be considered as belonging to one 
group, Palaeacanthaspidida. Kolymaspis stands apart from the representatives of this group. The new genus Kimaspis exhibits a number of similarities to Kolymaspis. The palaeacanthaspids have some remarkable characters, such as the presence of tesserae on the skull-roof in most of the forms, and a specific pattern of lateral line canals. E. Stensiö (1944), T. S. Westoll (1967) and other authors have shown that there is a relationship between the palaeacanthaspids and such groups as ptyctodonts and macropetalichthyids. The early occurrence, the limited stratigraphical distribution and the incompletely known structure of the representatives of this group render any find of palaeacanthaspids especially valuable. I am much indebted to colleagues A. Kim and N. Larin for the possibility to study the specimens of the new palaeacanthaspid. The specimens are in the Geological Museum of the Estonian Academy of Sciences (G.M.E.A., Pi).

\section{Kimaspis n. gen.}

D i a g nos is: Small form. The postethmoidal portion of the skullroof about $2 \mathrm{~cm}$ in length, lateral edges almost parallel, occipital margin with an embayment of moderate depth; the component plates of the skull-roof closely fused; external surface entirely (?) covered by tesserae; median face of the skull-roof separated from the lateral ones by well developed ridges. Large and long nuchal with a median elevation in its posterior portion. Centrals suture with each other. Posterior paranuchals large. Main lateral line and infraorbital canals enclosed into the bone tissue; partly open posterior pit-line grooves end at prominent pits with external openings of endolymphatic ducts. On the posterior paranuchal occurs the occipital cross commissure canal developed as an open groove. Median dorsal plate oblong and comparatively flat, with a weakly developed median ventral ridge.

S p e c i es: K. tienshanica n. sp.

\section{Kimaspis tienshanica n. sp.}

Type specimen: G.M.E.A. Pi 972, the holotype is a skull-roof (Text-figs. $1-4, \mathrm{P} 1$. I figs. $1-3$ ).

$\mathrm{D}$ i agnosis: Like for the genus (the only known species).

Material: Skull-roof $(\mathrm{Pi} 972)$ and median dorsal plate with its counterpart (Pi 973).

Formation: Lower Devonian, Gedinnian, Dzhalpak Formation.

Locality: South Tien Shan, the North Nuratau ridge, the southern slope of Merishkor mountain, lower part (beds No. 23) of the Dzhalpak Formation, by unpublished data of A. Kim and N. Larin. The specimens occur in organogenic limestone with algae, brachiopods and tabulata.

\section{Description}

Sku11-roof. The specimen Pi 972; the holotype (Text-figs. 1-4, Pl. I figs. $1-3$ ) represents the postethmoidal shield of a small skullroof of an almost equal length $(1.8 \mathrm{~cm})$ and width $(1.7 \mathrm{~cm})$. The specimen is slightly deformed, its natural convexity being preserved. The shape of the edges of the skull-roof cannot be established in detail. 


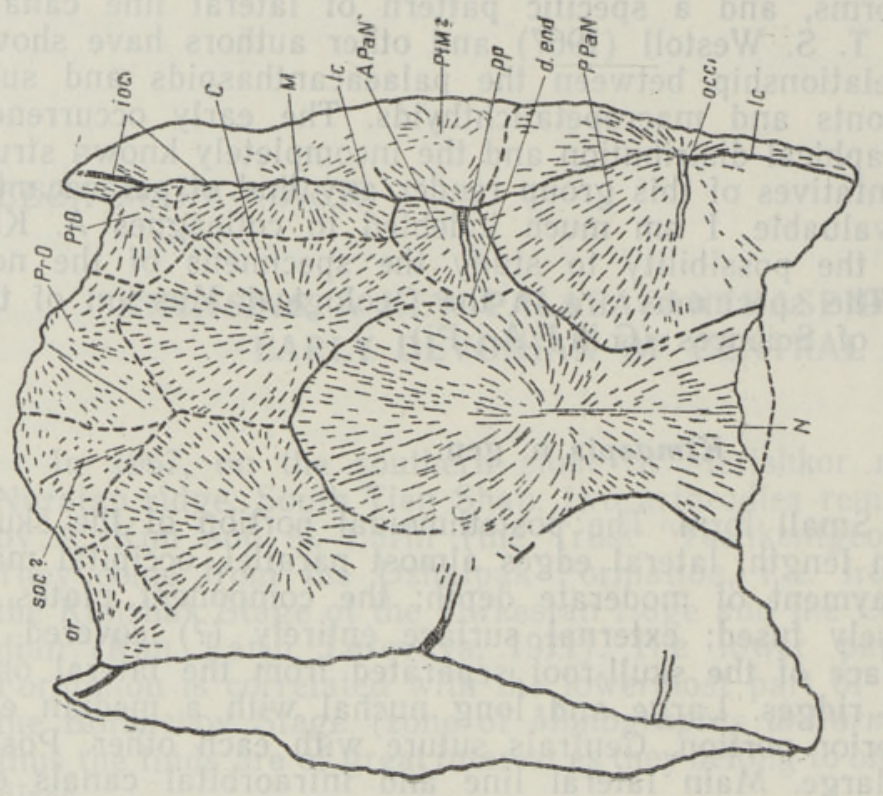

है

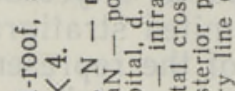

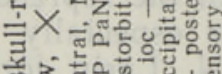

w

인

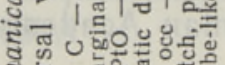

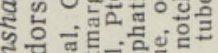

읭

计

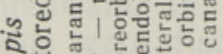

约设

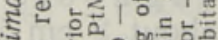

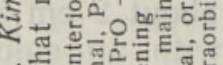

ง $\frac{1}{3}$ 때잉

造

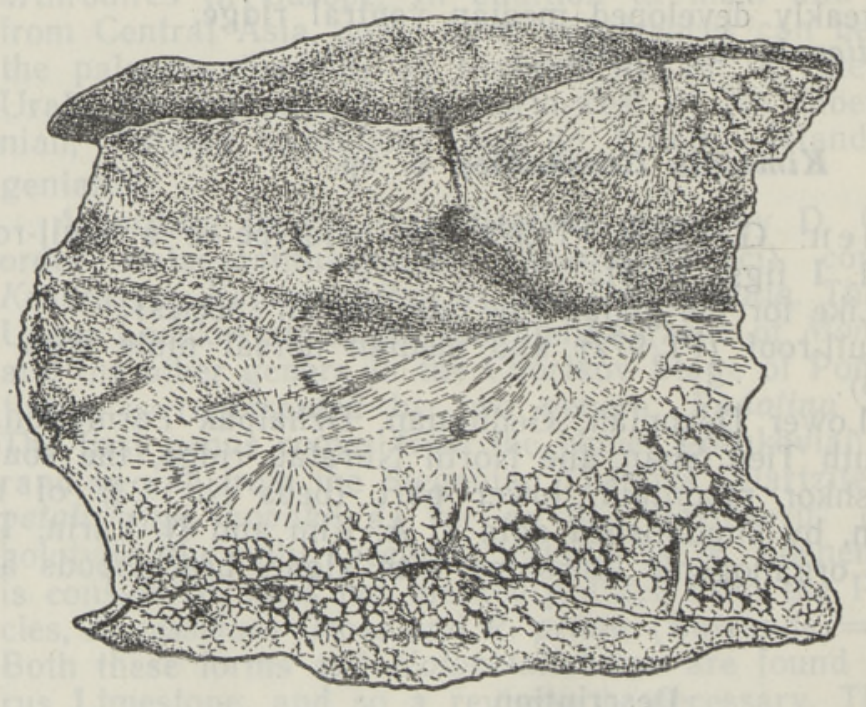

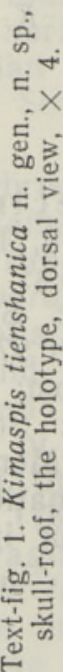


The skull-roof is divided into wide median and narrow lateral faces which are separated from each other by prominent longitudinal ridges produced by a change in the angle of the lateral slope from the median line and/or the thickening of the tissue. In the middle these ridges have

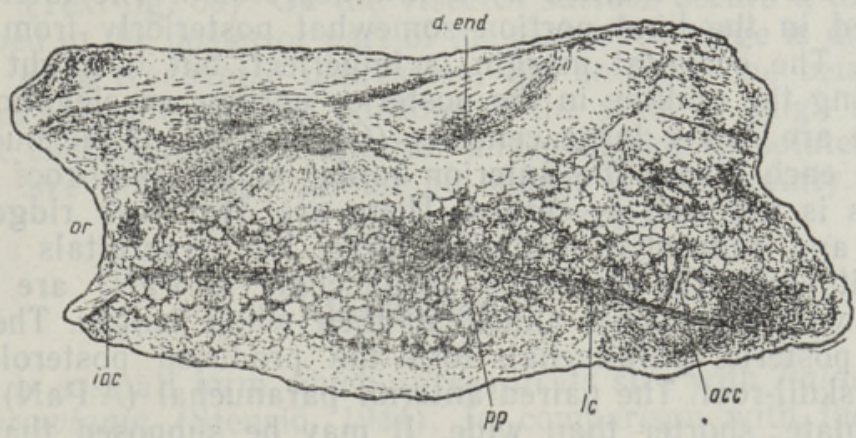

Text-fig. 3. Kimaspis tienshanica, skull-roof, lateral view, approx. $\times 4$. For lettering see Text-fig. 2.

medially directed embayments. Not far from the latter are placed rather deep depressions or pits with external openings of endolymphatic ducts (d. end, Text-figs. 2, 3). In transverse section the anterior portion of the skull-roof is trapezoid with a concavity in the middle (Text-fig. 4a). The posterior portion (Text-fig. 4b) is roof-shaped. Here the flanks of the medial face form an angle of $118^{\circ}$.
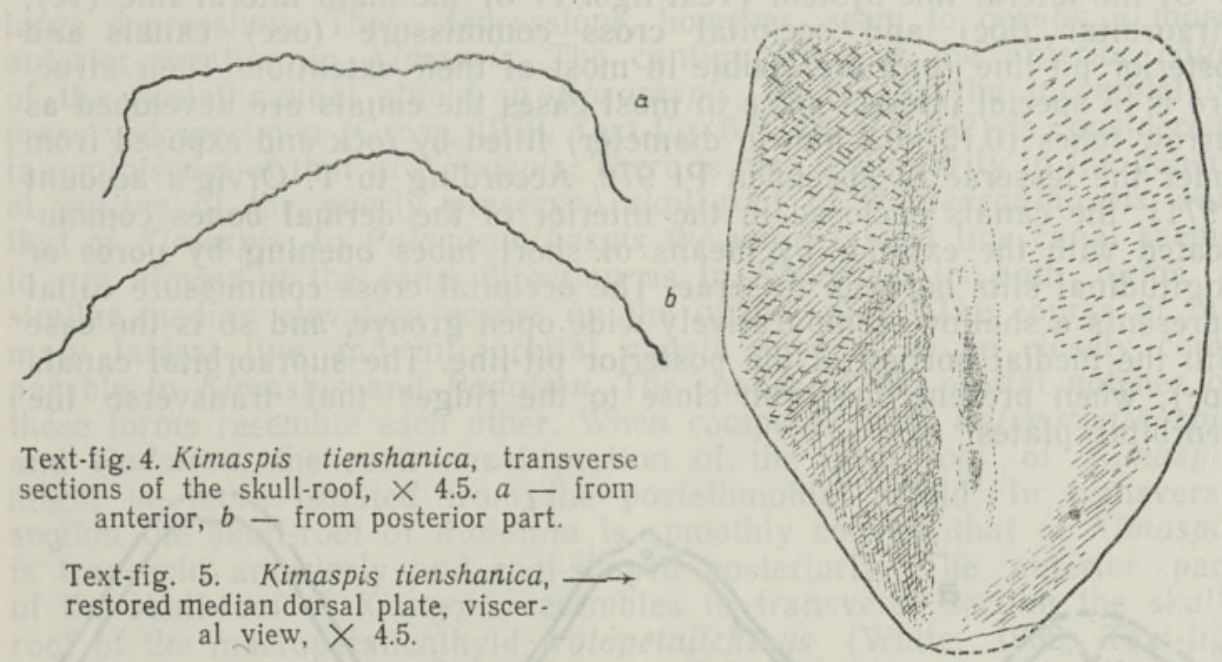

Text-fig. 4. Kimaspis tienshanica, transverse sections of the skull-roof, $\times$ 4.5. $a-$ from anterior, $b$ - from posterior part.

Text-fig. 5. Kimaspis tienshanica, restored median dorsal plate, visceral view, $\times 4.5$.

The external surface of the skull-roof is poorly preserved owing to the weathering or to the diagenetic alternations of the rock. On the left side tesserae can be traced almost in the whole length of the skull-roof. The single tesserae or their groups are scattered over the remaining portion of the skull-roof. It may be supposed that they covered the whole skull-roof or the major part of its surface. The tesserae (P1. I figs. 2, 3) are variable in size, small, the diameter of the larger ones being $0.5-$ $0.7 \mathrm{~mm}$. They are high, with an irregular polygonal configuration and bear one or a few simple stellate tubercles on their tops. Most of these tubercles, however, have been destroyed. 
On the surface exposed from ornamentation, closely fused plates can be distinguished with the help of bone radiation (Text-figs. 1,2). Their sutures are indistinct in many cases. The nuchal $(\mathrm{N})$ is a large plate which occupies more than a half of the whole length of the skull-roof. Its anterior border is marked by a low depression. The lateral margins are embayed in the hind portion somewhat posteriorly from the radiation centre. The occipital margin is imperfect, but it might have been convex. Along the midline in the posterior portion an elevation is developed. There are rather large centrals (C) in front of the nuchal, which suture with each other. The anterior border of the skull-roof in front of the centrals is not well preserved. There are two low ridges running backwards and somewhat medially. Here the preorbitals (PrO) are probably situated. The posterior paranuchals $(\mathrm{P} \mathrm{PaN})$ are also large and suture with the nuchal almost in their whole length. The hind portion of the posterior paranuchals form the produced posterolateral corners of the skull-roof. The paired anterior paranuchal ( $\mathrm{APaN})$ is a small polygonal plate, shorter than wide. It may be supposed that the postmarginal plate (PtM) occurs laterally from the anterior paranuchal. Some slight traces of a radiation centre and a convexity of the lateral margin of the skull-roof indicate its presence. The marginal $(M)$ is elongated, with a radiation centre approximately half-ways along the midline. The postorbitai (PtO) occupies a position in the anterolateral corner of the skull-roof. The anterior margin bounds the orbital notch (or) posteriorly. The plate is sinuous in transverse section. The lateral longitudinal ridge transverses the postorbital, marginal, anterior and posterior paranuchals.

Of the lateral line system (Text-figs. 1-3) the main lateral line (1c), infraorbital (ioc) and occipital cross commissure (occ) canals and posterior pit-line (pp) are visible in most of their extention. Their structure is of special interest since in most cases the canals are developed as narrow tubes $(0.15-0.2 \mathrm{~mm}$ in diameter) filled by rock and exposed from under the tesserae in specimen Pi 972. According to T. Orvig's account (1971), the canals enclosed in the interior of the dermal bones communicated with the exterior by means of short tubes opening by pores or longitudinal slits between tesserae. The occipital cross commissure canal represents a shallow, comparatively wide open groove, and so is the case with the medial portion of the posterior pit-line. The supraorbital canals (soc), when present, may run close to the ridges that transverse the preorbital plates.
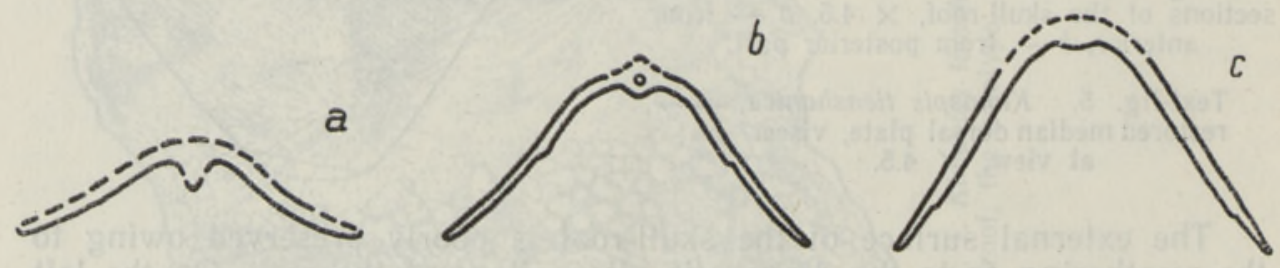

Text-fig. 6. Transverse sections of the median dorsals of palaeacanthaspids.

$a-$ Kimaspis tienshanica, $\times 3 ; b-$ Dobrowlania podolica, $\times 3 ; c-$ Palaeacanthaspis vasta, $\times 2.5$ $a$ - section through the plate at its maximum width: $b, c-$ by E. Stensiö (1944).

Median dorsal plate. The specimen Pi 973 (Text-figs. 5, 6a; Pl. I fig. 4, Pl. II fig. 1) is splitted into two parts: a fragment of the median dorsal plate exposed from the visceral surface and with broken lateral margins (Pl. I fig. 4), and a counterpart that shows the configu- 
ration of the lateral edges and bears some fragments with poorly preserved small round tubercles. The almost complete length of the plate is $1.4 \mathrm{~cm}$. The plate is longer than wide (Text-fig. 5); when restored the breadth: length index is 80 . The plate is rather flat; the flanks form an angle of $120^{\circ}$ (Text-fig. 6a). On the visceral surface occurs a low median ridge developed in the posterior part of the plate. The ridge is divided into two portions by a transverse depression, the anterior one being higher. The surface of the anterolateral portions of the plate is rough and seems to outline the contact faces for anterior and posterior dorsolateral plates, though their size and shape cannot be shown with certainty.

\section{Discussion}

Kimaspis is a small form which agrees in its size with Palaeacanthaspis and Dobrowlania (Stensiö, 1944). In comparison with these forms, Kosoraspis and Radotina are more than twice larger (Barrande, 1872; Gross, 1958, 1959; Westoll, 1967). The elongated skull-roof with roughly parallel lateral edges is characteristic of palaeacanthaspids in general, and so are the concave occipital margin and produced posterolateral corners of the skull-roof. In Kimaspis the posterior embayment seems to be shorter than in Kosoraspis and Radotina. The general shape of the skullroof in Kimaspis is closest to that in Kosoraspis. There are also some other features which agree in both genera, such as the course of the main lateral line canal and the posterior pit-line, the position of the external openings of the endolymphatic ducts, which are situated in large depressions. These depressions, however, seem to occupy a more anterior position in Kimaspis. The configuration of the anterior edge of the postethmoidal shield in Kosoraspis, as far as the incompletely preserved specimen (Gross, 1959, Text-fig. 6 B, Pl. 6 fig. 2) is considered, is reminiscent of that in Kimaspis. There is also a similarity in the general outline of the poorly preserved skull-roof of Palaeacanthaspis and that of Kimaspis. In Palaeacanthaspis the main lateral line canal seems to run almost in the same direction as in Kimaspis; in both forms a similar median elevation occurs on the nuchal plate. The course of the main lateral line and infraorbital canals appears to be closely comparable in Kimaspis and Radotina. The shapes of the orbital notches of these forms resemble each other. When compared with Palaeacanthaspis and Radotina, the rostronasal portion of the skull-roof of Kimaspis might be more isolated from the postethmoidal shield. In transverse section the skull-roof of Radotina is smoothly convex, that of Kimaspis is trapezoid anteriorly and roof-shaped posteriorly. The anterior part of the skull-roof of Kimaspis resembles in transverse section the skullroof of the macropetalichthyid Notopetalichthys (White, 1952, Text-fig. 37 ). The nuchal plate of Kimaspis is larger and longer than in Kosoraspis and Palaeacanthaspis. The nuchal and posterior paranuchal plates suture with each other in Kimaspis and Kosoraspis, which is not the case in Radotina. In the latter these plates are separated by long central plates.

Of the lateral line canals pattern in Kimaspis the presence of the occipital cross commissure canal is a feature of note, as it is not known in other palaeacanthaspids. In this respect Kimaspis resembles some arctolepids, such as Actinolepis and its related form from Spitzbergen (Mark-Kurik 1973). Both in these forms and Kimaspis the occipital region of the skull-roof is remarkably lengthened. 
The structure of the lateral line canals in Kimaspis deserves attention since it differs from that in other palaeacanthaspids. In the latter the canals are developed as open grooves, being often wide, especially in Radotina. In Kimaspis most of the canals (the main lateral line, the infraorbital canals and partly the posterior pit-line) are enclosed in narrow tubes in the interior of dermal bones, resembling the sensory line canals of some ptyctodonts (Ørvig, 1960, 1971) from the Middle and Upper Devonian. In Kimaspis the canals transverse the radiation centres of the component plates, which is not always the case, e.g., in Radotina.

The most remarkable feature of palaeacanthaspids is the tesseration of the skull-roof. On their skull-roof, the tesserae can be developed to a different degree. Some Radotina species seem to lack tesserae entirely, such as Radotina sp. from the Taunus quartzite and $R$. prima and so is the case with some Kosoraspis specimens. However, in the latter form the tesserae are sometimes very small, as W. Gross (1959) has noticed, and cannot always be distinguished from tubercles. When one compares Kimaspis with Kosoraspis and Radotina in this respect, the tesseration seems to be more developed in the first form. The tesserae occur in the radiation centres of centrals, which is not the case in Radotina.

There is a number of similarities between Kimaspis and Kolymaspis, an Early Devonian form from north-east Siberia. Kolymaspis, primarily. considered as an ostracoderm (Bystrow 1956), needs a further detailed description, especially for the remarkably well preserved endocranium. Kolymaspis is much larger than Kimaspis. In the first form the rostronasal portion is connected with the remaining portion of the skull-roof in a short stretch. Here lies one of the similarities between Kimaspis and Kolymaspis. In transverse section the anterior part of the postethmoidal shield is somewhat rounder in Kolymaspis (Pl. II fig. 2). The lateral line systems of Kimaspis and Kolymaspis show a number of similarities, primarily in their structure. It is highly probable that the ridges in the lateral portion of the skull-roof of Kolymaspis (Pl. II fig. 3) mark the position of the lateral line canals enclosed in the dermal bones. The lateral portion of the posterior pit-line has also a tube-like structure in Kolymaspis. The medial portion of this line as well as the middle pitline and supraorbital canal are developed as narrow open grooves. The ornamentation of Kolymaspis (Pl. II figs. 4, 5) consists of tubercles, larger and stellate in the rostral region and smaller and simpler on the greater part of the skull-roof.

Of the plates of the trunk-shield, only the median dorsal plate can be compared. The median dorsal plates of Palaeacanthaspis and Kosoraspis have a high median crest. In Kimaspis the dorsal side of the median dorsal is not exposed. The outline shape of the plate in Kimaspis resembles more that of Dobrowlania, but the median dorsal of the first form has more projecting anterolateral corners, and is slender posteri-

\section{Plate I}

Kimaspis tienshanica n. gen., n. sp.

Lower Devonian, Gedinnian, lower part of the Dzhalpak Formation, Merishkor mountain, North Nuratau, South Tien Shan.

Fig. 1. Skull-roof, the holotype, G.M.E.A., Pi 972, dorsal view, $\times 3.5$.

Figs. 2, 3. Ornamentation of the left flank of the holotype. Fig. $2, \times 5$; fig. $3, \times 10$.

Fig. 4. The counterpart of the median dorsal plate, Pi $973, \times 4$ 

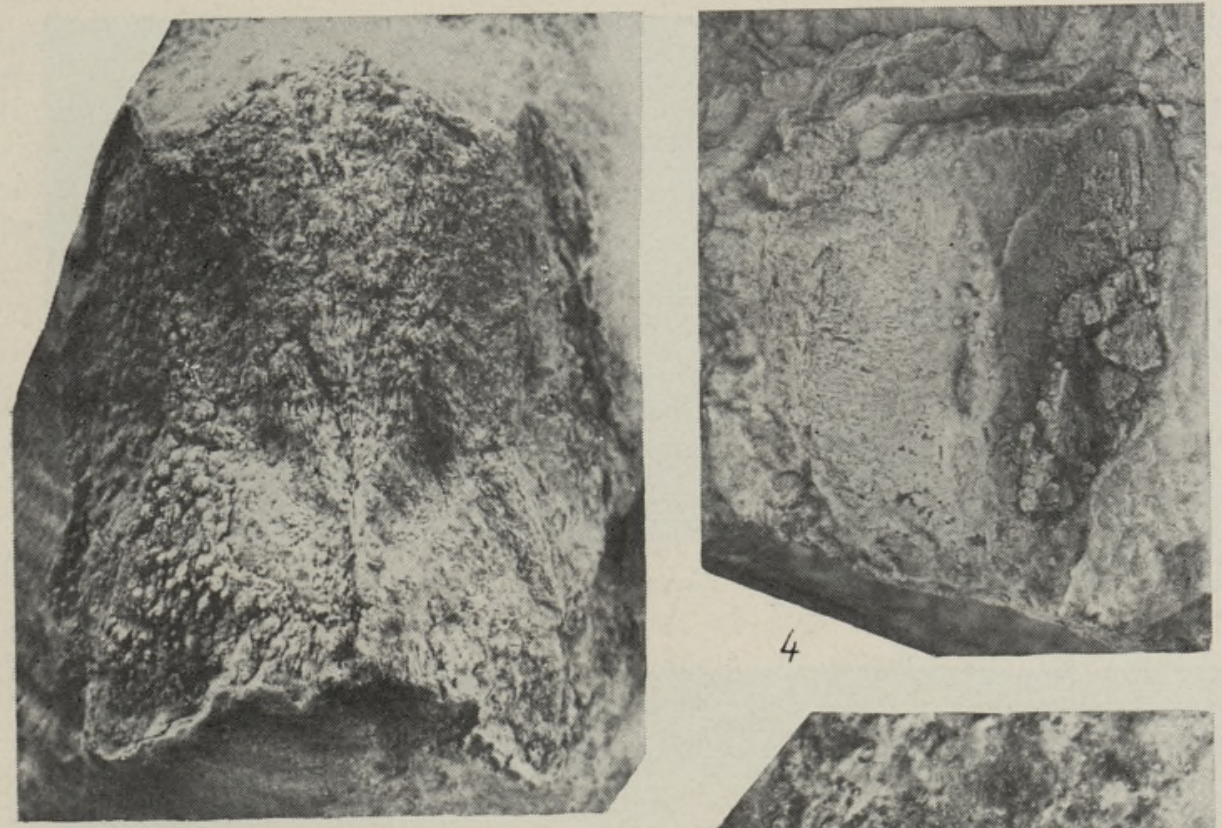

\section{1}
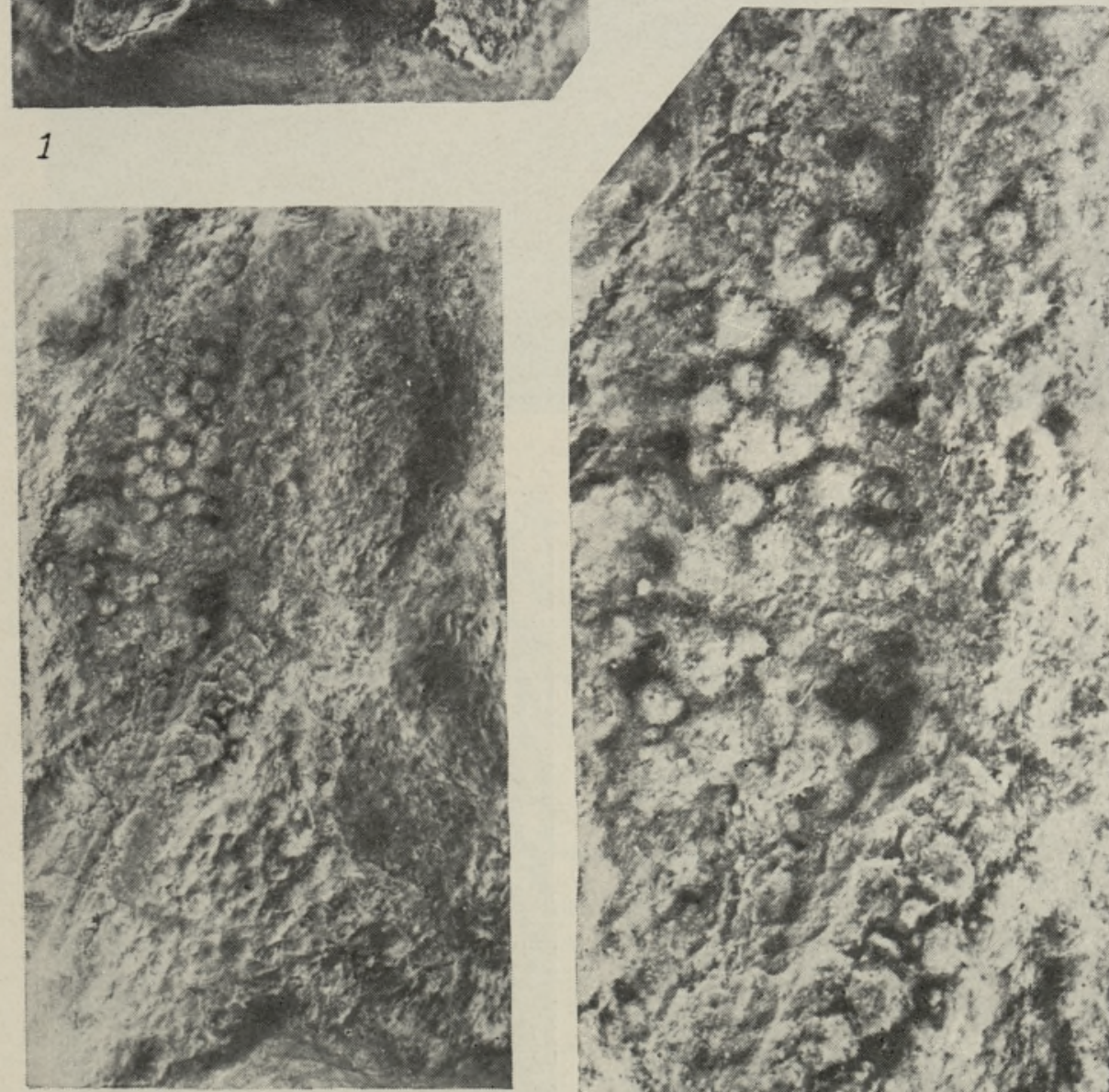

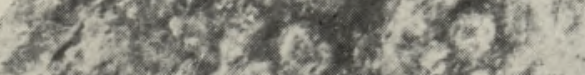

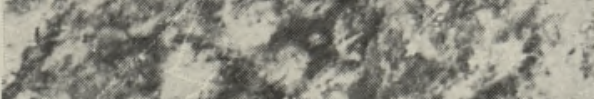

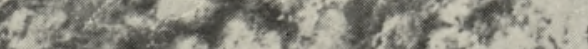

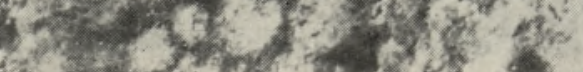

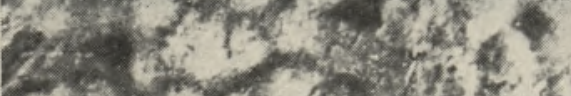

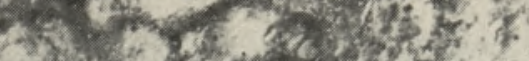

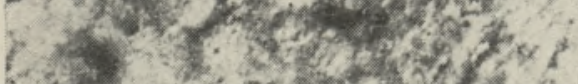

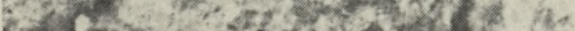

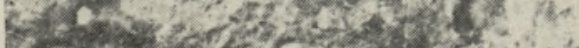

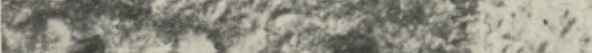

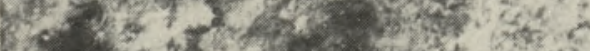
R.

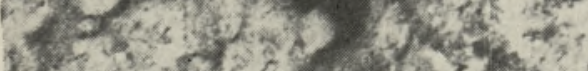

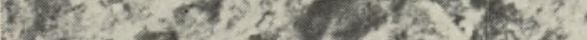
Y.

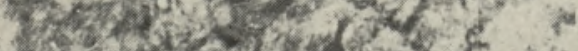

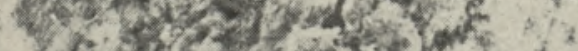

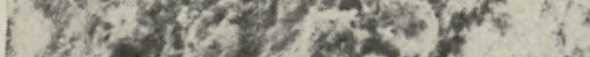

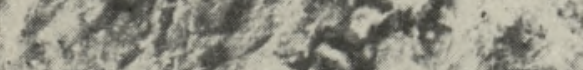

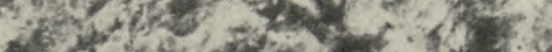
4.6. H.

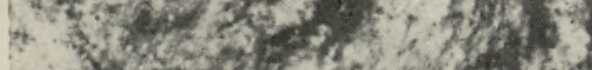

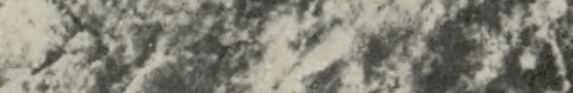

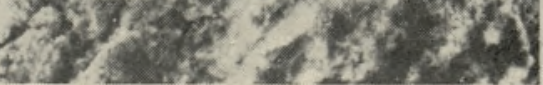



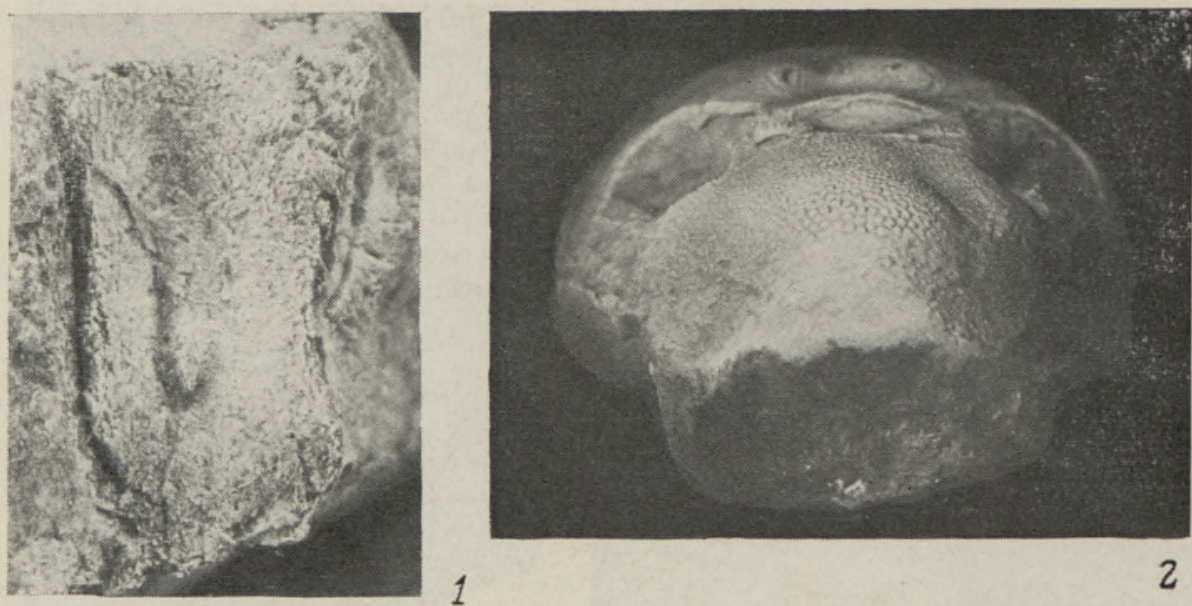

1

2

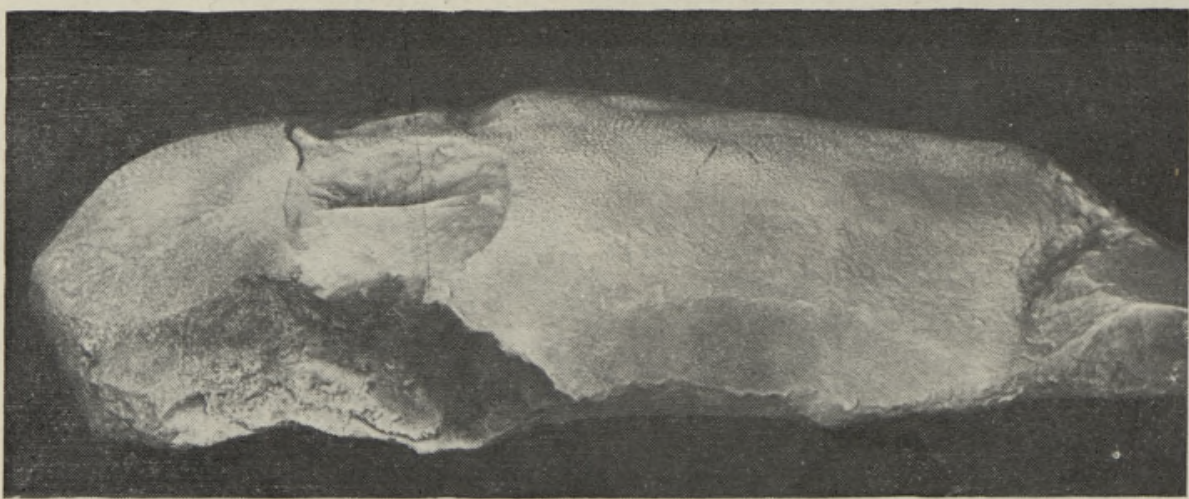

3

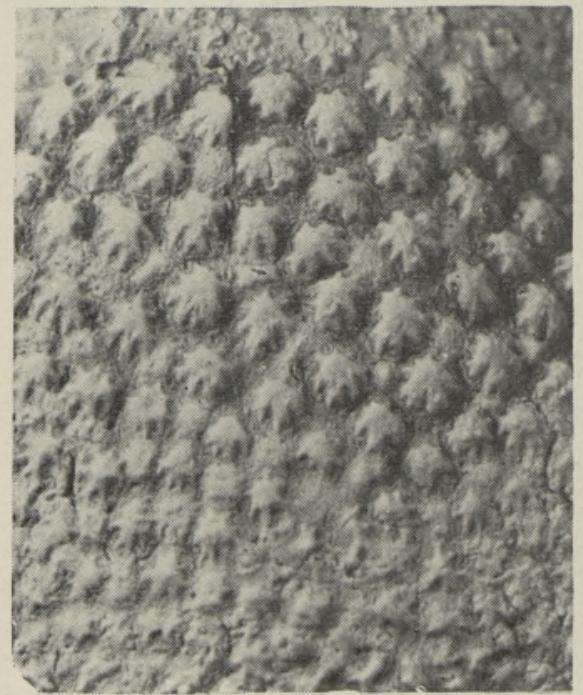

4

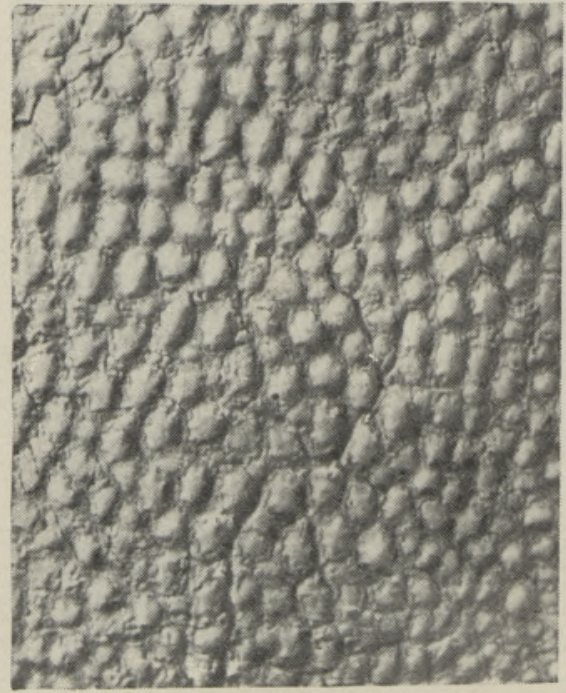


orly. In transverse section (Text-fig. 6) the median dorsal plates of Kimaspis, Dobrowlania and Palaeacanthaspis have a similar configuration, but their convexity is different. Kimaspis has the flattest plate, a condition that indicates the presence of a flatter thunk-shield in this form. The median ventral ridge is developed in all the mentioned palaeacanthaspids, being rather low, but differing in length.

\section{Conclusions}

Kimaspis n. gen. is one of the oldest arthrodires that can be placed in the family Palaeacanthaspididae Stensiö, 1944. It is closest to Kosoraspis, a palaeacanthaspid from the Upper Lochkovian, the Radotin limestone of Barrandian, as far as the skull-roof is considered. Kimaspis has some similarities with the other members of the family, Palaeacanthaspis and Dobrowlania from the Chortkov Stage (Gedinnian) of Polodia, as well as with Radotina from the Upper Lochkovian and Pragian of Barrandian. Such a feature of Kimaspis as the well developed tesseration seems to be connected with the early occurrence (in the zone of Monograptus uniformis), and can be considered as a primitive condition. The structure of the lateral line system and particularly the presence of the canals enclosed in the tubes, known so far only in ptyctodonts, may perhaps be regarded as a condition caused by the close relationship of Kimaspis to the hypothetical common ancestor of placoderms. The study of Kimaspis and its comparison with Kolymaspis has revealed some new characters in the structure of the latter form. Both Kimaspis and Kolymaspis have a similar structure of the lateral line system, some canals being developed as tubes enclosed in the bones of the dermal skeleton.

As to the biostratigraphical value, Kimaspis confirms the authenticity of the correlation of the lower part of the Lower Devonian in the North Nuratau region with that of Podolia and Barrandian given by A. Kim, N. Larin and A. Lesovaya (1971).

\section{REFEREN CES}

B a $\mathrm{r}$ a n d e J. 1872. Système Silurien du centre de la Bohème. I. Supplément au Vol. I. Trilobites, Crustacées divers et Poissons. Prague et Paris.

B ystrow A. 1956. Kolymaspis sibirica g. n., s. n. - новый представитель нижнедевонских бесчелюстных позвоночных. Вестн. ЛГУ, Сер. геол. и геопр., вып. 3, № 18.

Gross W. 1958. Uber die älteste Arthrodiren-Gattung. Notizbl. Hess. Landesamt. Bodenforsch. Wiesbaden, 86.

Gross W. 1959. Arthrodiren aus dem Obersilur der Prager Mulde. Palaeontographica A, 113 .

\section{Plate II}

Kimaspis tienshanica n. gen., n. sp.

Fig. 1. Median dorsal plate, $\mathrm{Pi} 973$, visceral view, $\times 4$.

Kolymaspis sibirica Bystrow, 1956

Lower Devonian, river Taskan, Kolyma basin, north-east Siberia.

Fig. 2. Skull-roof, type specimen (Chernyshev CNIGR Museum, Leningrad, No. 7656), anterior view, $\times 1$.

Fig. 3. The type specimen, lateral view, $\times 1$.

Fig. 4. Ornamentation of the rostral region of the type specimen, $\times 6$.

Fig. 5. Ornamentation of the central portion of the postethmoidal shield of the type specimen, $\times 6$.

4 ENSV TA Toimetised $\mathrm{K} \cdot \mathrm{G}-41973$ 
K im A., Larin N., Lesov a y A. 1971. Проблема границы силура-девона и расчленение нижнего девона в Средней Азии. В сб.: Граница силура и девона и биостратиграфия силура, Тр. 111 Междунар. симп., 1, Л.

Koenen A. 1895. Uber einige Fischreste des norddeutschen und böhmischen Devons. Abh. Ges. Wiss. Göttingen, 40.

Mark-KurikE. 1973. Actinolepis (Arthrodira) from the Middle Devonian of Estonia. Palaeontographica A, 143, No. $1-6$.

Miles R. S. 1967. The cervical joint and some aspects of the origin of the Placodermi. Colloques Int. Cent. Natn. Rech. Scient., 163.

Obruchev D. 1964. Класс Placodermi. В кн.: Основы палеонтологии. Бесчелюстные, рыбы. Ред. Д. В. Обручев. М.

$\varnothing$ rvig T. 1960. New finds of Acanthodians, Arthrodires, Crossopterygians, Ganoids and Dipnoans in the Upper Middle Devonian calcareous flags (Oberer Plattenkalk) of the Bergisch Gladbach - Paffrath Trough. Pt. 1. Paläont. Z., 34, Nr. 3/4.

Ørvig T. 1971. Comments on the lateral line system of some brachythoracid and ptyctodontid arthrodires. Zool. Sc., 1.

StensiöE. 1944. Contribution to the knowledge of the vertebrate fauna of the Silurian and Devonian of Western Podolia. II. Ark. Zool., 35 A, No. 9.

Westoll T. S. 1967. Radotina and other tesserate fishes. J. Linn. Soc. (Zool.), 47, No. 311 .

Wh it e E. I. 1952. Australian arthrodires. Bull. Br. Mus. (Nat. Hist.) Geol., 1, No. 9.

$$
\begin{gathered}
\text { Academy of Sciences of the Estonian SSR, } \\
\text { Institute of Geology }
\end{gathered}
$$

March 2, 1973

\section{ELGA MARK-KURIK}

\section{KIMASPIS, UUS PALEAKANTASPIID KESK-AASIA ALAMDEVONIST}

Artiklis kirjeldatakse vanimaid artrodiiride perekonda Kimaspis n. gen. Nuratau mäeaheliku (Lõuna Tjan-San) alamdevoni Džalpaki kihistikust. Džalpaki kihistik vastab Borštšovi lademele Podoolia ning Lohkovi lademele Tšehhi läbilōikes ehk Monograptus uniformis'e tsoonile. Uus paleakantaspiidide perekond sarnaneb kōige enam perekond Kosoraspis'ega Tšehhi ülemlohkovist. Tal on ka ühiseid jooni Kolōma basseini alamdevonis esineva Kolymaspis'ega. Huvitavaks iseärasuseks nii Kimaspis'el kui ka Kolymaspis'el on torutaoliste küljejoonte kanalite olemasolu, mida seni teati esinevat vaid kōrgematel artrodiiridel-ptüktodontiididel.

\section{ЭЛЬГА МАРК-КУРИК}

\section{KIMASPIS, НОВЫИ ПАЛЕАКАНТАСПИД ИЗ РАННЕГО ДЕВОНА СРЕДНЕИ АЗИИ}

Остатки древних артродир палеакантаспид, распространенных в нижнем девоне (жедин-зиген) Евразии, довольно редкие. Находки из Южного Тянь-Шаня (Северный Нуратау, южный склон горы Меришкор) принадлежат новому представителю этой группы - Kimaspis n. gen. Остатки Kimaspis собраны в 1967 г. А. И. Кимом и Н. М. Лариным (трест «Ташкентгеология», КГГПЭ) из нижней части джалпакской свиты, т. е. из аналогов кунжакского горизонта Туркестанского хребта и лохкова Баррандиена на уровне зоны Monograptus uniformis.

У Kimaspis tienshanica n. gen., n. sp. известны крыша черепа (голотип, Геологический музей АН ЭССР, $\mathrm{Pi} 972$; рис. $1-4$, табл. I, фиг. 1-3) и mediodorsale, $\mathrm{Pi} 973$ (рис. 5,6 ; табл. I, фиг. 4 , табл. II, фиг. 1). Д и а г о з года (и единственного вида): Небольшая форма. Постэтмойдальный щит крыши черепа длиной около 2 см, боковые края почти параллельны, задний край умеренно вогнут. Крыша черепа состоит из сливщихся костей, покрытых полностью (?) тессерами. Nuchale крупное и длинное. Centralia граничат друг с другом. Задние paranuchalia крупные. Собственнобоковой (1c) и подглазничный (ioc) каналы имеют вид трубочек, проходящих под тессерами; задняя ямочная линия (pp) кончается в виде открытой борозды возле наружного отверстия эндолимфатического канала (d. end); на заднем paranuchale имеется затылочная поперечная борозда (осc.). Mediodorsale удлиненное, довольно плоское со слабо развитым продольным валиком на висцеральной стороне.

По строению крыши черепа род Kimaspis наиболее близок к Kosoraspis из верхнего лохкова Баррандиена (зона Monograptus hercynicus), но имеет ряд общих признаков с другими палеакантаспидами, а также с родственной им формой Kolymaspis (ранний дөвон северо-востока Сибири). 